\title{
The Urgency Mechanism of Industrial Relation's Settle- ment to Support the Business Climate that Equitable for Workers
}

\author{
Agisa Tri Handias* and Muhamad Azhar \\ Master of Law, Faculty of Law, Diponegoro University \\ *email: agisatri@gmail.com
}

Published: 15/09/2020

How to cite (in APA style):

Handidas, A, T., Azhar, M. (2020). The Urgency Mechanism of Industrial Relation's Settlement to Support the Business Climate that Equitable for Workers. Jurnal Hukum Prasada, 7(2), 66-72. doi: https://doi.org/10.22225/ jhp.7.2.2116.66-72

\begin{abstract}
Indonesia has been developed in economical sector, especially in the employment section. Along with the times, there has occur and grown up and many problems about employment matter in which there many more employment relationship works without parity between the responsibility and the rights from the employer to the employee/ workers. As the consequence of the inclusion of business competition climate, it caused the businessman look for ways how to maximize the production output by reducing the costs. This circumstance has influenced the workers right becomes ruled out and then arises statement of workers to claim their pending rights. This study aims to find out the industrial relationship matter related to the business competition climate, and to find out the settlement mechanism of industrial relationship conflict based on regulation number 2 year of 2004 about settlement of industrial relationship matter. This study used juridical normative method. This juridical research is carried out towards references object. Moreover, this study applied primary, secondary, and tertiary legal material. The result of the study showed that the impact of employment matter was more complicated. That is why the labor problems should be seen as the industrial relation matter. This matter also comes as the consequence of Indonesia as the Welfare State where the State should take a part in every part of social life. This means that the State has important role to solve the problem of industrial relationship.
\end{abstract}

Keyword: Businessman; Business Competition Climate; Industrial Relation Matters; Worker

\section{INTRODUCTION}

The unitary state of Republic of Indonesia is a country that stand to the law. This matter has been clearly written in the Fundamental Constitution of the Republic of Indonesia year of 1945 article 1 section (3). As the consequence of a state law, The State must be able to apply the equitable regulations that based on to the Human Rights toward all people. Moreover, The State should take part to manage every community life. The employment matter is included into this. As the aftermath, there were some changes related to the employment regulation or labour law. At first, the labour law is included to the civil law, but then change to public law aspect in which is meant to The State Administrative Law.

The recent of modern industrial era is absolutely affected the business competition that has been more tight and sharp. This condition continuously brings problems over employment, especially in the work relation between employer and employee. Moreover, the problems of employment that has more widespread and complicated must be consider as industrial relation conflict, and also the settlement of it. There some different opinion 
between businessman and the worker/ labour. This can cause any conflict that need to be finished. When the conflict arise between employee and the employer, it will cause the inequity in the work relationship. Furthermore, it will affect the stability of production of economic development, and even worse it will affect the wide community life. Therefore, the action of the government as an effort to solve the conflict between those parties is so important. It can be very helpful for both parties.

For labours, work relationship termination and other consequence of it, means they should face the new start of jobless life. There should be no work relationship termination to ensure the certainty and the tranquillity of labours, (Djumialdji, 1986). Therefore, the existed theory has showed that the improvement of work should increase the number of the entire workforce, (Soemitro, 1980). The State effort to solve the problems here is very important.

Based on article 1 section 1 of Statute Number 2 ear of 2004 about the settlement of industrial relationship conflict, it explain that the conflict of industrial relationship is different opinion that can cause a disagreement between businessman or company and the employee/ labours or labour union because there was disagreement about rights, conflict of purpose, conflict of work relationship termination among labour union in a company.

The regulation number 2 year of 2004 about the settlement of industrial relationship problems has been arranged the procedure of settlement that must be followed by employer and the employee. It is a provision that tells about the beginning of the settlement that should be solved as bipartite way, in which if there could not find any solutions, it will be continued to the next step of conciliation, arbitration, mediation, or the further way is proposing a lawsuit to the industrial relationship court. Some similar study have been conducted previously by some researchers, such as Firdaus \& Sonhaji (2016) which conducted a study entitled "Juridical Review of Termination of Employment Dispute Resolution Process". The results of this study showed that all forms of dispute resolution that the parties have undergone based on Law Number 2 of 2004 concerning Settlement of Industrial Relations Disputes in accordance with applicable regulations. Furthermore, regarding the decision of the Panel of Judges in the Supreme Court Decision, according to the author, it is in accordance with statutory provisions. Judging from the consideration of the Panel of Judges stating that the workers' rights have actually been fulfilled by the employer, where this is evidenced by the opinion of the Panel of Judges which states that the worker is considered to be leaving or resigning from his job due to failing to fulfill his obligations until the agreed date of expiration of the work agreement. Based on these considerations, workers do not receive severance pay. This has been regulated in Law Number 13 of 2003 concerning Manpower. Moreover, Latip, Lu'luiaily, \& Ainiyah (2019) also conducted the similar study entitled "Mediation as a Solution to the Problems of Workers in Bangkalan Regency". The results of this study showed that as stated in Article 1 Number 10 of Law Number 2 of 2004 concerning Industrial Relations Dispute Settlement, hereinafter referred to as the PPHI Law states that bipartite negotiations are negotiations between workers/laborers or trade/labor unions and employers to resolve industrial relations disputes. Meanwhile, tripartite negotiations are the settlement of industrial relations disputes through a third party.

Based on the background of the problem and the latest related study above, thusthis study aims to find out the industrial relationship matter related to the business competition climate, and to find out the settlement mechanism of industrial relationship conflict based on regulation number 2 year of 2004 about settlement of industrial relationship matter

\section{METHOD}

Juridical normative is used as the method of this study. Juridical normative method is a research of law that did by doing research of book references material or from secondary data, (Soekanto, 2014). This study applied primary, secondary, and tertiary legal material. Meanwhile, this study used analytical descriptive as the study specification. It is a references material research to describe and analyze the problem in description way.

\section{DISCUSSION}




\section{The Industrial Relationship matter related to the Business Competition Climate}

Basically, the regulation about labour rights and responsibility of work is an effort from The Government to solve the problems relate to employment. Moreover, Indonesia has a fast development in overcoming the employment especially the work relationship. It has been started since the Declaration of International Labour Organization (ILO) has released in the year of 1988 . That statement requires all of Country to ratify the eight basic convention of that declaration that included the natural labour rights. Indonesia as the Welfare State did their effort to take a part in every social life of their people. It is different to the capitalist liberal concept that decline the involvement of The Government towards people industrial and economy sector.

There some requirement to be completed as the implementation of legal protection towards the worker. Those are, a liberty for workers and their family to have a better standard of living, a prevention of the reduction or loss of income and purchasing power, especially for workers / labourers, and an assurance for the workers if they lost their job and income because of work accident, disease, or passed away, (Kahfi, 2016). For centuries, the problem of employment matter seems never been done and always bear the protection, equity, salary, welfare, guidance and supervision, conflict and the solution, and also the regulation matter about employment, (Sutedi, 2009).

Let's begin with the very first problem of employment that happened in Indonesia. It is a problem between the employee and the employer. As time goes by, this matter was getting worse because there many imbalance of work relationship between the both side, especially about the work agreement. The condition of Indonesia that in developing process of economy is affecting the company of business to do their effort to reduce the cost of production so that efficient enough to minimalize the business competition. Furthermore, this requires the employee has a high demand of works. This condition always happens as the consequence of business competition climate. Then, the problem of employment not only involve the employee and the employer, but also involve the other part. It is included the government or other department/ institution under the government, (Kahfi, 2016). This matter of labour/ worker relationship are getting complicated. It covers the whole industrial aspect. Furthermore, the labour matter should be consider as industrial relationship matter, (Kahfi, 2016). Related to this, the statute number 13 year of 2003 about employment is one of legal protection towards the industrial relationship regulation.

In the article 5 of statute number 13 year of 2003 about employment is written that every single employee has the same opportunity and not to be discriminated to get a job. Next, in the article 6 is written that every single worker/ employee has rights to get the same treatment without any discrimination from the employer. This statute was made as the implementation of article 27 section (2) of The Constitution of Republic of Indonesia year of 1945 where it explains that every single citizen has rights to get a good job and worthy human life. Continue to the article 28D section (2) The Constitution of Republic of Indonesia year of 1945, it explains that every person has rights to work and get salary and the equitable and worthy treatment in the working relationship. Clearly stated here that there are protection and prohibition to distinguish the gender, ethnic, race, and religion in order to get a job. Therefore, the protection of law and worker rights must be held without having any discrimination.

Based on the whole article in the statute number 13 year of 2003 about employment, it can be conclude that the range of protection towards worker are: (Wahyudi, 2016)

The primary rights of worker/ employee to have discussed with the employer;

Safety and health of work;

A particular protection towards woman worker, child, and people with disability; and

A protection over salary, welfare, and social security of employment.

The agreement of employment is a deal between the both parties, especially for the new employee as their initial stage of joining the company. The agreement of employment has some requirements to be completed by both side. According to the theory, the requirements are: 
Individual bargaining. It is a requirement of work which consist of provision that related to the requirement of work. The provision only involve the worker/ employee as an individual (person), this means involve the worker/ employee toward the employer or company. Furthermore it is called Individual Bargaining, (Haryani, 2002). Requirement of work that considering the employment association, it will ask the condition where the worker/employee to accept the points that already agreed by the employer or company with the worker representative, (Haryani).

Unfortunately, the employer often lack of concern to the worker's welfare and rights. It makes the work agreement is inequitably implemented. Otherwise, the worker is in the disadvantageous side where they have no power towards the company that has the bigger authority to determine the company's policy. This condition is contrary to the Pancasila as the guideline of Indonesia. Industrial relationship system that implemented in Indonesia is a Pancasila based system in which the stakeholder must always implement their role refers to the values of the nation's philosophy. Here, the stakeholder are the worker, businessman, and the government and the nation's philosophy are the values of Pancasila itself. The values of Pancasila that must be implemented will create the good, pleasant, peaceful and orderly circumstance and environment of work. The values of Pancasila and The Constitution of Republic of Indonesia Year of 1945 can control the human behavior. Human can become more virtuous, righteous, respect each other, helping each other, balancing, preventing from selfishness, underestimating other, and blackmailing other, (Zulkarnaen, 2018). In the end, the industrial relationship system is supposed to have a big impact in order to realized the national economy that according to Pancasila. There is important to have a mutualism symbiosis where the employer must give and appreciate the worker rights, so that the welfare of worker can be achieved and the worker can implement their vision and mission to fulfill the company's goal.

Besides of the statute of employee rights, the protection for worker also important in the process of industrial relationship conflict settlement. However there is a party that has a bigger ability to carry out their intention to come true. Therefore, it is important to uphold the equality before the law principle in various settlement procedure of industrial relation matter by the employee and the employer. When the process is running, there is supposed no partiality for either the employer or the employee until they face the judicial process. Moreover, the employee of worker must understand the rules that has been created by the government about their rights during completing their job. So they will know how the rules of their work agreement is running. They will know is the rights and the responsibility between the employee and the employer are already fulfilled or is there any inequity.

The current development of free global market is affecting the business competition climate becomes higher. The businessman absolutely will find ways to distribute their product into the very smallest part of social life. This makes the businessman push the worker in order to finish the productivity. In the end, the labor rights is ignored. Here comes the industrial relationship conflict. It can be misunderstand of rights, conflict of interest, working relationship conflict, and a conflict among labor union. To face this condition, the government has released the statute number 2 year of 2004 about The Settlement of Industrial Relationship conflict to solve and reduce the conflict between the both sides. This statute is hoped can give a law protection for workers who got the disadvantages from the employer by using the equality before the law's principle.

\section{The Settlement Mechanism of Industrial Relationship Conflict according to Statute Number 2 Year of 2004 About Settlement of Industrial Relationship Conflict.}

Manpower has a role as a development force to face the national productivity and social welfare, (Charda, 2017). Unfortunately there is a gap between Das Sollen and Das Sein. There is a gap between the theory and the reality or a gap between the theoretical state of law and the empirical facts, (Wijayanti, 2018). The employer or company did not fulfill the worker rights in often way. It caused an imbalance between the rights and the responsibility in which does not accordance to the statute number 13 year of 2003 about employment. Therefore, the protection for worker/ employee is unseparated to the protection for citizen as the responsibility of The Country to protect them, (Muin, 2015). A 
protection towards manpower is important and must be strived to support the worker to get their natural rights. There will be a conflict of industrial relationship if the rights not run well. Furthermore, if there is no settlement for the problem, the circumstance will get tense and will affect the economy of Indonesia.

If the settlement between the worker/employee and the employer is only on their own hands, it will be difficult to gain the vision of labour law as the tool to create the social justice because the superior side will always have power over the inferior one, (Husni, 2000). Meanwhile, it should be well understood if the justice for the people will give them a welfare, peace, and prosperity of life.

The government has a big role as the mediator to this matter. Refer to it, there are regulations included in the statute about employment. For example, the statute number 13 year of 2003 about employment and statute number 2 year of 2004 about the settlement of industrial relationship matter. Therefore, the settlement of the conflict between the businessman and the worker can be achieved, and also the worker can get an element of productivity propriety attitude, togetherness, and justice for everyone, (Sutedi, 2009).

One of the industrial relationship matter is a different opinion that can cause a conflict between the businessman or joint business and the worker/ employee or labour union. It can be caused by disputes of rights, disputes of interest, disputes because the work relationship termination and a conflict among worker/ labour union in the same company. According to the general regulation from the statute number 2 year of 2004 about the settlement of the industrial relationship matter, it explained some points from the definitions. That are:

The conflict of rights is a conflict because the rights are not fulfilled. It can be influenced by the different of understanding or implementation about the regulations, work agreement, the rules of the company, or the contract that already agreed by them. The regulation about manpower has been written in the statute number 13 year of 2003 about employment;

Conflict of interest is a conflict that happened because there is different opinion about the preparation, and/or any changes of the work requirements that agreed in the contract, or company rules, or collective labour agreement;

Conflict of work relationship termination is a conflict that came because there is a different opinion about the termination of work relationship by one of the parties;

Conflict among worker/ labour union is a conflict that happened between a worker/ labour union and other worker/ labour union in the same company. It happened because there was no understanding agreement about membership, implementation of rights, and the responsibility of worker association.

The existed regulation explains the step of settlement of industrial relationship conflict. These problems will not be immediately submitted to the Industrial Relations Court, but previously had to go through a series of stages of resolution. It begins with bipartite settlement, which is a business process to find the solution of the problems through deliberation or decision making by negotiation between the workers/ employee and the employer. This process must be completed within 30 days. If the settlement is achieved, an agreement is made which should be signed by the both parties. Then, it must be registered to the district court of Industrial Relationship where the agreement is made. According to article 7 section (5), if the agreement is not implemented, the injured party may submit an application for execution to the Industrial Relationship Court. If the conflict is not solved, the bipartite deemed to have failed and one or both of the parties can continue to an agency that has responsibility for manpower affair or to the Local Employment Office by attaching the evidence of bipartite.

Next, Article 4 number 2 of The Statute Year of 2004 about Settlement of Industrial Relationship Conflict, the settlement process at the Office of Manpower Affair will offer a settlement of conflict through conciliation or arbitration. Still in the same Article, it is explained that conciliation aims to solve the conflict of interest, termination of work relationship, or among worker/labor union. Meanwhile, the settlement through arbitration is 
carry out to settle the conflict of interest or conflict among worker/ laborer union. If the parties still have no any determination to choose which settlement path within 7 days, then the settlement will be taken over by the mediator. As the agreement is running, then:

If the settlement is through a mediation, then a mutual agreement is made;

If the settlement is through a conciliation, then a mutual agreement is made;

If the settlement is through an arbitration and a reconciliation is achieved, then deed of peace is made. Meanwhile if the reconciliation is failed, then will be continued to arbitration hearing.

When the settlement effort has been attempted and failed, the parties can only file a lawsuit to the first level Industrial Relations Court. Based on Article 56 of Law Number 2 Year of 2004 concerning Settlement of Industrial Relations Disputes that the Industrial Relations Court has the duty and authority to examine and decide:

At the first level is concerning conflict over rights;

At the first and last level regarding conflict of interest;

At the first level is concerning conflict over termination of work relationship;

At the first and last level is concerning the conflict among labour unions/ union in the same company.

In the procedural law of industrial relations affair's settlement is not regulated regarding the legal remedies of appeal, so that the legal remedies of appeal do not applicable here, but it is directly to the appeal of cassation, and only disputes over rights and termination of employment that can be filed for legal remedies.

The statute number 2 year of 2004 concerning the settlement of industrial relations number 10 is affirming the statement above. To assure the fast, precise, fair and cheap settlement, the settlement of industrial relations disputes through the Industrial Relations Court in the general court environment is limited in the process and stages by not allowing any opportunity to file an appeal. When one of the parties is not satisfy with the result over the conflict of rights and termination of work relations that is released by Industrial Relation Court as the first stage court, the party can submit an appeal to the Supreme Court. However, the matter related to conflict of interest and conflict among labor union cannot be filed as appeal because the decision is the first and final adjudication.

\section{CONCLUSION}

The amount of employment conflict that occur in Indonesia that is experienced by the worker and the employer just getting worse because the work relationship is imbalance between both parties, especially in the terms of employment agreement. Indonesia, which is experiencing development in economy sector, put through the company to do efficiency in production cost in order to reduce business competition and have an impact on the high work demands of their workers. Those problems are keep arising as the impact of the business competition climate. In this case, The Government should be involved in order to reduce the existing problems. The problems are getting complicated and labor issue must be consider as a matter of Industrial Relations. The regulations regarding the settlement of Industrial Relations disputes are written in the statute Number 2 Year of 2004 concerning The Settlement of Industrial Relations Conflict. Every conflict that occurs, must be solved through bipartite settlement at the first place. When a settlement is achieved, then a mutual agreement is made. In the other side, when the settlement is beyond reach, then the bipartite settlement is considered as failed. After that, one or both parties can continue the conflict to the responsible agency over employment or to the local Employment Affair Department. This matter can be solved by conciliation, arbitration, or mediation way. If those method of settlement are still failed, then a lawsuit can be filed by the parties to the first level Industrial Relations Court. Considering that there is no appeal in the procedural law, this means only legal appeal can be attempted. Disputes that may be appealed for cassation only concern disputes over rights and termination of employment. Meanwhile the Industrial Relations adjudication towards conflict of interest and conflict among trade union/ labor union is only a first and final court adjudication. 


\section{REFERENCES}

Charda, U. (2017). Model Penyelesaian Perselisihan Hubungan Industrial dalam Hukum Ketenagakerjaan Setelah Lahirnya Undang-Undang Nomor 2 Tahun 2004. Jurnal Wawasan Yuridika, 1(1), 1. doi:10.25072/jwy.v1i1.124

Djumialdji. (1986). Pemutusan Hubungan Kerja. Jakarta: Bina Aksara.

Firdaus, D., \& Sonhaji, S. (2016). Tinjauan Yuridis Proses Penyelesaian Perselisihan Pemutusan Hubungan Kerja (PHK) pada Pengadilan Hubungan Industrial (Analisis Putusan Mahkamah Agung No.83K/Pdt.Sus-PHI/2015). Diponegoro Law Journal, 5(4), 1-12. Retrieved from https://ejournal3.undip.ac.id/index.php/dlr/article/view/13747

Haryani, S. (2002). Hubungan Industrial di Indonesia. Yogyakarta: UPP AMP YKPN.

Husni, L. (2000). Pengantar Hukum Ketenagakerjaan Indonesia. Jakarta: PT Raja Grafindo Persada.

Kahfi, A. (2016). Perlindungan Hukum Terhadap Tenaga Kerja. Jurisprudentie: Jurusan IImu Hukum Fakultas Syariah Dan Hukum, 3(2), 59-72. doi: https://doi.org/10.24252/ jurisprudentie.v3i2.2665

Latip, A., Lu'luiaily, L., \& Ainiyah, A. (2019). Mediasi sebagai Penyelesaian Permasalahan Tenaga Kerja di Kabupaten Bangkalan. Competence: Journal of Management Studies, 12(2), 65-89. doi:10.21107/kompetensi.v12i2.4950

Muin, F. (2015). Perlindungan Hukum Terhadap Tenaga Kerja Indonesia (Tinjauan Terhadap UU Nomor 39 Tahun 2004 Tentang Penempatan dan Perlindungan Tenaga Kerja Indonesia). JURNAL CITA HUKUM, 3(1), 11-24. doi:10.15408/jch.v2i1.1838

Soekanto, S. (2014). Penelitian Hukum Normatif, Suatu Tinjauan Singkat. Jakarta: PT Raja Grafindo Persada.

Soemitro, R. H. (1980). Permasalahan Hukum di dalam Masyarakat. Bandung: Alumni.

Sutedi, A. (2009a). Hukum Perburuhan. Jakarta: Sinar Grafika.

Wahyudi, E. (2016). Hukum Ketenagakerjaan. Jakarta: Sinar Grafika.

Wijayanti, R. (2018). Effectiveness of Legal Protection on Employees/Labours in a Fixed-Term Employment Contract in Golden Tulip Bay View Hotel \& Convention-Bali. Jurnal Hukum Prasada, 5(2), 90-99. doi:https://doi.org/10.22225/jhp.5.2.761.90-99

Zulkarnaen, A. H. (2018). Masalah Rawan dalam Hubungan Industrial dan Konsep Negara Kesejahteraan Indonesia. Jurnal Hukum Mimbar Justitia, 2(2), 806. doi:10.35194/jhmj.v2i2.32 